\title{
Low serum hyaluronic acid levels associated with spontaneous HBsAg clearance
}

\author{
S. Harkisoen ${ }^{1}$ - J. E. Arends ${ }^{1}$ - A. van den Hoek $^{2,3}$ • K. J. van Erpecum ${ }^{4}$ - G. J. Boland ${ }^{5}$. \\ A. I. M. Hoepelman ${ }^{1}$
}

Received: 27 March 2015 / Accepted: 2 August 2015 /Published online: 21 August 2015

(C) The Author(s) 2015. This article is published with open access at Springerlink.com

\begin{abstract}
Purpose The pathophysiological underlying mechanism of spontaneous HBsAg clearance in hepatitis B virus (HBV) infected patients is largely unknown. However, serum hyaluronic acid (sHA) plays a role in liver fibrosis progression and reversely could serve as a potential biomarker for HBsAg clearance. This study investigates whether low sHA is associated with HBsAg loss in non-Asian HBV patients.

Methods Non-Asian women living in Amsterdam with known chronic HBV infection between 1990-2003 were invited for a single follow-up visit at the Municipal Health Service Amsterdam between September 2011 to May 2012. Serum hyaluronic acid and liver stiffness measurement together with clinical evaluation, biochemical and virologic blood tests were performed.

Results Of the 160 women, HBsAg loss occurred in 38 (23\%) patients between diagnosis and follow-up. sHA levels were lower in HBsAg negative patients compared to HBsAg positive patients (14.5 [9.4-27.2] ng/mL vs 25.0 [12.3-42.5] ng/
\end{abstract}

S. Harkisoen

s.harkisoen@umcutrecht.nl

1 Department of Internal Medicine and Infectious Diseases, University Medical Center Utrecht, Heidelberglaan 100, P.O. Box 85500, F02.126, 3508, GA Utrecht, The Netherlands

2 Department of Infectious diseases, Public Health Service of Amsterdam (GGD), Amsterdam, The Netherlands

3 Department of Internal Medicine, Division of Infectious Diseases, Tropical Medicine and AIDS, Academic Medical Center, Amsterdam, The Netherlands

4 Department of Gastroenterology and Hepatology, University Medical Center Utrecht, Utrecht, The Netherlands

5 Department of Medical Microbiology, University Medical Center Utrecht, Utrecht, The Netherlands
$\mathrm{mL}, p<0.01$ ). A similar distinction in sHA between low and high HBV DNA was noted. sHA had a significant discriminatory ability to differentiate between $\mathrm{HBsAg}$ positive and HBsAg negative patients, (AUC 0.65 [95 \% CI 0.55-0.75], $p<0.01)$. In multivariable analysis only sHA level was associated with HBsAg loss (OR 0.4 [0.2-0.9]). Finally, F3-F4 fibrosis (cut-off $>8.1 \mathrm{kPa}$ ) was diagnosed in $3 \%$ in $\mathrm{HBsAg}$ negative patients compared to $10 \%$ in $\mathrm{HBsAg}$ positive patients $(p=0.15)$.

Conclusion Serum HA levels are lower in patients who experience spontaneous HBsAg loss compared to $\mathrm{HBsAg}$ positive patients.

\section{Introduction}

Liver inflammation is the hallmark of hepatotropic viruses like hepatitis B virus (HBV). During this chronic hepatic inflammation, synthesis and turnover of the extracellular matrix (ECM) is modulated by several cytokines with serum hyaluronic acid (sHA) being one of its major ECM components $[1,2]$. In healthy persons, sHA levels vary between 23 and $129 \mathrm{ng} / \mathrm{mL}[3,4]$. sHA levels have already been shown to be higher in patients with chronic hepatitis $\mathrm{C}$ or active autoimmune hepatitis than those of healthy individuals without signs of hepatitis [5-7]. In addition, in chronic HBeAg negative HBV patients, high serum sHA positively correlates with fibrosis progression and level of inflammation [8]. Based on these observations, sHA level might be a reflection of the intensity of the immune response in chronic liver diseases.

Annually, approximately $2 \%$ of all chronic hepatitis B virus (HBV) infected patients experience HBV surface antigen (HBsAg) loss without antiviral therapy (i.e. spontaneous HBsAg clearance) [9]. Although the exact pathophysiological mechanism of spontaneous HBsAg loss in patients with 
chronic HBV has not been fully understood, there is some evidence that a T-cell mediated immune response may be essential in this process [10]. Rehermann et al. [11] demonstrated that chronic HBV patients who cleared HBsAg, spontaneously or after interferon-alfa treatment, had a strong HBV multispecific cytotoxic T-lymphocyte response that was similar to those clearing HBsAg after an acute infection. Several histological studies have shown that after spontaneous HBsAg loss, liver inflammation declined over time [12, 13]. However, it is unknown whether sHA levels also decline after spontaneous HBsAg loss and if sHA could serve as a potential biomarker for HBsAg clearance. The aim of this study was to investigate whether a low sHA level is associated with HBsAg loss in patients with chronic HBV.

\section{Materials and methods}

\section{Patient selection}

The study population has already been described previously [14]. Briefly, non-Asian women in the greater Amsterdam area, who were registered as chronic HBV patients between 1990 and 2004, were invited for a single study visit between September 2011 and May 2012 at the Municipal Health Service of Amsterdam. History taking and physical examination were performed, along with a liver stiffness measurement (LSM) and blood tests to determine the hyaluronic acid level and biochemical and virological tests. The following biochemical tests were determined: bilirubin, alanine aminotransferase (ALT), aspartate aminotransferase (AST), Gammaglutamyl transpeptidase (GGT), alkaline phosphatase (ALP) and albumin. For this study 14 patients were excluded from the 174 included patients (three with HCV co-infection, five with previous HBV treatment, one with acute $\mathrm{HBV}$ infection and five due to indeterminate sHA which was a result of not enough serum to determine the sHA), resulting in a study population of 160 participants.

Spontaneous HBsAg loss was defined as having a positive HBsAg antigen in the historic sample with subsequent HBsAg negativity during the follow-up visit without previously being subjected to antiviral therapy. The study protocol was approved by the Ethical Committee of the Academic Medical Center Amsterdam. Written approval was obtained from the Public Health Service Amsterdam. Informed consent was obtained from each participant (clinical trials number NCT01462981).

\section{Laboratory tests}

Hyaluronic acid levels were measured in serum at the followup visit as part of the ELF-test by the ADVIA Centaur XP (Siemens, Erlangen, Germany). This assay has a lower detection limit of $1.6 \mathrm{ng} / \mathrm{ml}$, a linear range from 1.6 to $1000 \mathrm{ng} / \mathrm{ml}$, and higher concentrations are expressed as $>1000 \mathrm{ng} / \mathrm{ml}$. Linearity, sensitivity and precision were evaluated according to CLSI guidelines. HBV DNA was determined with the COBAS Ampliprep/COBAS Taqman assay, v.2.0 (Roche Molecular Diagnostics, California, USA) with a lower detection limit of $20 \mathrm{IU} / \mathrm{ml}$. Qualitative anti-HCV, anti-HIV and qualitative HBsAg were also performed with the ADVIA Centaur XP assay. Lastly, liver-related biochemical parameters were determined according to local standard laboratory procedures. HBV DNA levels were divided in more or less than $2000 \mathrm{IU} / \mathrm{mL}$ that was derived from current international guidelines $[15,16]$.

\section{Liver stiffness measurement}

An experienced researcher (S.H.) performed the LSM with a Fibroscan ${ }^{\circledR}$ (model F402 Echosens, France) according to standard operating procedures supplied by the manufacturer and as described by others [17]. The METAVIR classification was used to determine the fibrosis stage, categorizing no to mild fibrosis (F0/F2) with a score less than or equal to $8.1 \mathrm{kPa}$ and severe fibrosis to cirrhosis (F3/F4) with a score above $8.1 \mathrm{kPa}$ based on a cut-off value from previous studies in chronic HBV patients $[18,19]$.

\section{Statistical analysis}

Continuous variables were expressed as a median with interquartile range (IQR) and categorical variables as frequencies with percentage. Differences between HBsAg positive and HBsAg negative groups were calculated with the MannWhitney U test (continuous variables) or chi-square test (categorical variables). Factors associated with HBsAg loss were analysed with univariable and multivariable logistic regression. Factors with a p-value $<0.10$ in univariable analysis were included in the multivariable logistic regression. Correlation between ALT levels and SHA levels were calculated with the Spearman rho correlation. A receiver-operator characteristic (ROC) curve was constructed to assess the value of sHA in discriminating HBsAg positive patients from HBsAg negative patients and to determine an optimal cut-off value for the sHA. A ROC curve with an area under curve (AUC) less than 0.60 and a p-value $>0.05$ was considered unreliable for the ROC curve. Outcomes were reported as odds ratio (OR) with $95 \%$ confidence intervals (CI), and a p-value $<0.05$ was considered significant. The statistical analysis was performed with SPSS v17 (version 17.0; SPSS Inc., Chicago, IL, USA).

\section{Results}

Patient characteristics are given in Table 1. At the time of the follow-up study visit, HBsAg loss was documented in 38 
Table 1 Characteristics of the study population by HBsAg status

\begin{tabular}{|c|c|c|c|}
\hline Characteristic & HBsAg positive patients $(\mathrm{N}=122)$ & HBsAg negative patients $(\mathrm{N}=38)$ & p-value \\
\hline Age, years median (IQR) & $45(41-49)$ & $44(39-48)$ & 0.57 \\
\hline Follow-up, years median (IQR) & $18(13-20)$ & $18(14-20)$ & 0.85 \\
\hline BMI, $\mathrm{kg} / \mathrm{m}^{2}$ median (IQR) & $30(27-33)$ & $29(25-34)$ & 0.85 \\
\hline Alcohol, $n(\%)^{a}$ & $39(31)$ & $5(13)$ & 0.02 \\
\hline Smoking, $n(\%)^{b}$ & $28(23)$ & $3(8)$ & 0.03 \\
\hline Origin, $n(\%)$ & & & 0.04 \\
\hline Turkey & $33(27)$ & $19(50)$ & \\
\hline Ghana & $31(25)$ & $3(8)$ & \\
\hline Surinam & $25(21)$ & $5(13)$ & \\
\hline Morocco & $24(20)$ & $7(18)$ & \\
\hline Other & $9(7)$ & $4(11)$ & \\
\hline ALT, U/L median (IQR) & $18(15-26)$ & $16(12-21)$ & 0.11 \\
\hline AST, U/L median (IQR) & $17(13-23)$ & $15(12-19)$ & 0.16 \\
\hline Trombocytes, $10^{9} / L$ median $(I Q R)$ & $249(201-287)$ & $245(218-284)$ & 0.94 \\
\hline Protrombin time, seconds median (IQR) & $13.1(12.8-13.5)$ & $13.2(12.6-13.5)$ & 0.82 \\
\hline Log HBV DNA, IU/mL median (IQR) & $2.7(1.9-3.5)$ & $\mathrm{n} / \mathrm{a}$ & $\mathrm{n} / \mathrm{a}$ \\
\hline F3-F4 fibrosis, $n(\%)^{c}$ & $12(10)$ & $1(3)$ & 0.15 \\
\hline
\end{tabular}

$B M I$ body mass index, $A L T$ alanine aminotransferase, $A S T$ aspartate aminotransferase, $I Q R$ interquartile range, $U / L$ units per liter, $I U / m L$ international units per milliliter, $n / a$ not applicable

${ }^{\text {a }}$ Alcohol consumption defined as more than one glass per week

b Smoking defined as more than one cigarette per week

${ }^{\mathrm{c}}$ Determined by liver stiffness measurement

(23\%) patients resulting in $122 \mathrm{HBsAg}$ positive patients, all being $\mathrm{HBeAg}$ negative. All HBsAg negative patients had an undetectable HBV DNA level (i.e. $<20 \mathrm{IU} / \mathrm{ml}$ ). Of the 117 patients with a liver stiffness result, occurrence of F3-F4 fibrosis was lower in the HBsAg negative patients compared to HBsAg positive patients (one in $38 \mathrm{HBsAg}$ negative patients (3\%) vs 12 in $122 \mathrm{HBsAg}$ positive patients $(10 \%), p=0.15)$.

\section{Hyaluronic acid level and HBV parameters}

To explore whether sHA levels were different between HBsAg positive and HBsAg negative patients, sHA levels were compared in both groups. The median (IQR) sHA level of all included patients was $21.9(11.7-41.2) \mathrm{ng} / \mathrm{mL}$. HBsAg negative patients had a significantly lower sHA level compared to HBsAg positive patients (14.5 [9.4-27.2] ng/mL vs 25.0 [12.3-42.5] ng/mL, $\mathrm{p}<0.01$ ) (Fig. 1). In addition, when patients were categorized into low HBV DNA level (HBV DNA less than or equal to $2000 \mathrm{IU} / \mathrm{mL}$ ) and high $\mathrm{HBV}$ DNA level (HBV DNA $>2000 \mathrm{IU} / \mathrm{mL}$ ), there was a trend towards lower sHA levels in the low HBV DNA patients compared to the patients with high HBV DNA (20.6 [11.2-40.4] $\mathrm{ng} / \mathrm{mL}$ vs 26.3 [14.7-44.4] ng/mL, $p=0.07$ ).

Overall, there was a positive correlation between sHA levels and ALT level in the whole study population $(\mathrm{r}=0.20$, $\mathrm{p}=0.01$ ) (data not shown). However, when patients were divided by HBsAg status, this correlation was lost (HBsAg positive group $\mathrm{r}=0.16, p=0.08$ and $\mathrm{HBs} A \mathrm{~g}$ negative group, $\mathrm{r}=0.11, p=0.49$ ). The sHA had a significant diagnostic discriminatory power to detect $\mathrm{HBsAg}$ negative patients (AUC 0.65 [95\% CI 0.55-0.75], $p<0.01$ ). A cut-off value of $16.9 \mathrm{ng} / \mathrm{mL}$ was selected to have the optimum in both sensitivity and specificity. Subsequently, patients were divided in two groups, either low or high sHA. There were 68 (43\%) patients with a low sHA level compared to 92 (57\%) patients with a high sHA level. Of the $38 \mathrm{HBsAg}$ negative patients, 25 (66\%) had a low sHA level (i.e. below $16.9 \mathrm{ng} / \mathrm{mL}$ ) and 13 (34\%) a high sHA level.

\section{Factors associated with HBsAg loss}

Next, we performed univariable and multivariable analyses to identify factors that were associated with HBsAg loss. The results are shown in Table 2. In univariable analysis, which included age, BMI, ethnic origin, smoking, alcohol consumption, ALT level, AST level, sHA level, HBV DNA and fibrosis stage as factors, alcohol consumption [OR $0.3(0.1-0.9)]$ and a high sHA level [OR $0.3(0.1-0.6)$ ] were associated with increased chance to loose HBsAg. BMI, smoking, and ALT level had a close, but statistically not significant association with HBsAg loss [BMI OR 0.5 (0.2-1.1), smoking OR 0.3 $(0.1-1.0)$ and ALT OR $0.5(0.2-1.0)]$. When all significant or 
Fig. 1 Distribution of serum hyaluronic acid according to HBsAg status (a), HBV DNA level (b) and fibrosis stage (c). LSMliver stiffness measurement

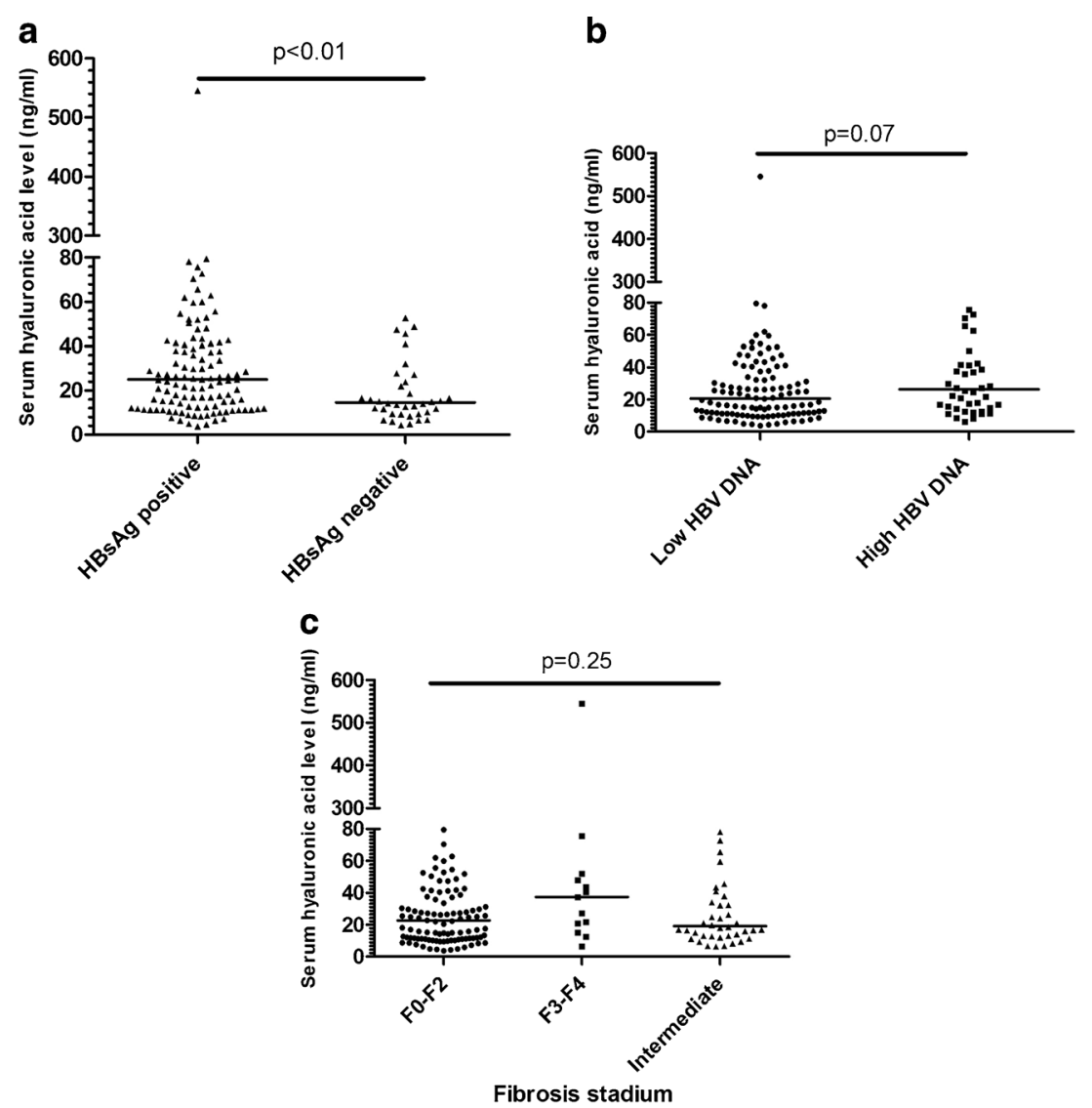

borderline significant factors from univariable analysis were included in a multivariable analysis, only those patients with a high sHA level had a lower chance to lose HBsAg (OR 0.4 [0.2-0.8]).

\section{Discussion}

Spontaneous HBsAg loss in chronic HBV-infected patients is a phenomenon that is still not well understood. This study clearly shows that chronically HBV infected patients who lost HBsAg had lower sHA levels compared to patients who remained positive.

Though not reported in the literature previously, there are several arguments to explain this finding. First, sHA is a ligand of CD44 that is expressed in numerous cells, including liver sinus endothelial cells, neutrophils and regulatory T-cells (Tregs) [20, 21]. Data from experimental studies in other diseases have shown that there is an interplay between sHA and the immune system during chronic inflammation. On the one hand, studies in lung fibroblasts have shown that cytokines such as TNF-a activate the production of sHA [22]. Subsequent sHA-CD44 binding then promotes T-cell adhesion and migration to the endothelium to engage in an inflammatory process. On the other hand, there is also evidence that
sHA stimulates the anti-inflammatory pathway of the immune system [23]. In an in vitro study, sHA binding to CD44 was correlated with a high suppressive activity of Tregs [23].

Second, in chronic HBV-infected patients experiencing spontaneous HBsAg loss, early studies have shown that the inflammatory process in the liver declined after HBsAg clearance $[12,13]$. Although the interplay between sHA, inflammation and HBsAg loss has to be further elucidated, we hypothesize that HBsAg loss dampens the immune system which in turn suppresses the synthesis of sHA leading to low sHA levels.

Several studies have investigated the value of sHA (or sHA as a component of the enhanced liver fibrosis [ELF] test) in patients with chronic HBV [8, 24-31]. However, these studies differ in several aspects from our study. First, until now studies in HBV patients have only focused on the role of sHA in the identification of liver fibrosis. Second, the study population of previous studies differed from our study, since previous studies either included only HBsAg positive patients or did not separate patients based on their HBsAg status (when HBsAg status of the included patients was not mentioned). Third, the cut-off value of the sHA concentration in our study is much lower than the cut-off values of other studies which varied between 52 and $300 \mathrm{ng} / \mathrm{mL}[25,27]$. Since we have shown that lower sHA values than previously reported are necessary 
Table 2 Analysis of factors associated with spontaneous HBsAg loss

\begin{tabular}{|c|c|c|c|c|c|c|}
\hline Factor & Total $(\mathrm{N})$ & $\begin{array}{l}\text { HBsAg negative } \\
\text { cases }(\%)\end{array}$ & $\begin{array}{l}\text { Univariable analysis } \\
\text { OR }(95 \% \mathrm{CI})\end{array}$ & p-value & $\begin{array}{l}\text { Multivariable analysis } \\
\text { OR }(95 \% \mathrm{CI})\end{array}$ & p-value \\
\hline \multicolumn{7}{|l|}{ Age } \\
\hline$\leq 45$ years & 85 & $22(26)$ & 1 (reference) & \multirow[t]{2}{*}{0.50} & \multirow[t]{2}{*}{1 (reference) } & \\
\hline$>45$ years & 75 & $16(21)$ & $0.8(0.4-1.6)$ & & & \\
\hline \multicolumn{7}{|l|}{ BMI } \\
\hline$\leq 25 \mathrm{~kg} / \mathrm{m}^{2}$ & 24 & $9(38)$ & 1 (reference) & \multirow[t]{2}{*}{0.09} & 1 (reference) & \multirow[t]{2}{*}{0.10} \\
\hline$>25 \mathrm{~kg} / \mathrm{m}^{2}$ & 136 & $29(21)$ & $0.5(0.2-1.1)$ & & $0.4(0.2-1.2)$ & \\
\hline \multicolumn{7}{|l|}{ Ethnic origin } \\
\hline Turkey & 52 & $19(37)$ & 1 (reference) & \multirow[t]{5}{*}{0.18} & \multirow[t]{5}{*}{1 (reference) } & \\
\hline Ghana & 34 & $3(9)$ & $1.3(0.4-4.9)$ & & & \\
\hline Surinam & 30 & $5(17)$ & $0.2(0.1-1.2)$ & & & \\
\hline Morocco & 31 & $7(23)$ & $0.5(0.1-2.1)$ & & & \\
\hline Other origin & 108 & $19(18)$ & $0.7(0.2-2.8)$ & & & \\
\hline \multicolumn{7}{|l|}{ Smoking $^{\mathrm{a}}$} \\
\hline No & 129 & $35(27)$ & 1 (reference) & \multirow{2}{*}{0.05} & 1 (reference) & \multirow{2}{*}{0.06} \\
\hline Yes & 31 & $3(10)$ & $0.3(0.1-1.0)$ & & $0.3(0.1-1.1)$ & \\
\hline \multicolumn{7}{|c|}{ Alcohol consumption ${ }^{\mathrm{b}}$} \\
\hline No & 116 & $33(28)$ & 1 (reference) & \multirow[t]{2}{*}{0.03} & 1 (reference) & \multirow{2}{*}{0.17} \\
\hline Yes & 44 & $5(11)$ & $0.3(0.1-0.9)$ & & $0.5(0.2-1.4)$ & \\
\hline \multicolumn{7}{|l|}{ ALT } \\
\hline$\leq 0.5 \times \mathrm{ULN}$ & 88 & $26(30)$ & 1 (reference) & \multirow[t]{2}{*}{0.06} & 1 (reference) & \multirow[t]{2}{*}{0.26} \\
\hline$>0.5 \times$ ULN & 72 & $12(17)$ & $0.5(0.2-1.0)$ & & $0.6(0.3-1.4)$ & \\
\hline \multicolumn{7}{|l|}{ AST } \\
\hline$\leq 0.5 \times \mathrm{ULN}$ & 150 & $38(25)$ & 1 (reference) & & \multirow[t]{2}{*}{1 (reference) } & \\
\hline$>0.5 \times$ ULN & 10 & $0(0)$ & $\mathrm{n} / \mathrm{a}$ & & & \\
\hline \multicolumn{7}{|l|}{ HA level } \\
\hline Low & 68 & $25(37)$ & 1 (reference) & \multirow[t]{2}{*}{$<0.01$} & 1 (reference) & \multirow[t]{2}{*}{0.01} \\
\hline High & 92 & $13(14)$ & $0.3(0.1-0.6)$ & & $0.4(0.2-0.8)$ & \\
\hline \multicolumn{7}{|l|}{ HBV DNA level } \\
\hline Low/undetectable & 118 & $38(32)$ & 1 (reference) & & \multirow[t]{2}{*}{1 (reference) } & \\
\hline High & 42 & $0(0)$ & $\mathrm{n} / \mathrm{a}$ & & & \\
\hline \multicolumn{7}{|l|}{ Fibrosis stage } \\
\hline F3-F4 & 13 & $1(8)$ & 1 (reference) & \multirow[t]{3}{*}{0.17} & \multirow[t]{3}{*}{1 (reference) } & \\
\hline $\mathrm{F} 0-\mathrm{F} 2$ & 105 & $23(22)$ & $5.8(0.7-49.1)$ & & & \\
\hline Indeterminate & 42 & $14(33)$ & $3.4(0.4-27.6)$ & & & \\
\hline
\end{tabular}

$B M I$ body mass index, $A L T$ alanine aminotransferase, $A S T$ aspartate aminotransferase, $U L N$ upper limit of normal, $O R$ odds ratio, $95 \% C I 95$ percent confidence interval, $n / a$ not applicable

a Smoking defined as more than one cigarette per week

b Alcohol consumption defined as more than one glass per week

to differentiate between patients with and without spontaneous HBsAg loss, this association could have gone unnoticed by others.

Since this was a cross-sectional study, we could not explore whether the sHA levels could be of predictive value to identify future candidates for spontaneous HBsAg loss. A prospective longitudinal study with multiple time points in which sHA levels would be determined and in which the moment of HBsAg loss is documented is needed to clarify this question. This would also allow for exploration of additional variables, which could be fitted into an algorithm, to identify chronic HBV patients who will experience spontaneous HBsAg loss in an early stage to avoid unnecessary antiviral therapy. The advantage of sHA is that it is easily accessible and available, relatively inexpensive and a small amount of serum is required for the assay.

In conclusion, serum HA levels are significantly lower in chronic $\mathrm{HBeAg}$ negative HBV patients who experience spontaneous HBsAg loss in comparison to those still being HBsAg positive. Further validation studies are needed to determine 
the predictive value of sHA with potential other variables in the natural history of chronic HBV.

Funding The study was supported by an unrestricted grant from Gilead Sciences NV.

Conflict of interest Soeradj Harkisoen: no conflict of interest; Joop E. Arends: participates in advisory board of Roche, BMS, Janssen, Abbvie and MSD, Speakers Bureau Gilead; Anneke van den Hoek: no conflict of interest; Karel J. van Erpecum: was member of advisory boards of BMS and Abbvie and received research support by Schering Plough; Greet J. Boland: no conflict of interest; Andy I.M. Hoepelman: received grants from Roche, Gilead, Merck and ViiV Healthcare and is an advisor for Gilead, Merck, ViiV Healthcare and Janssen.

Open AccessThis article is distributed under the terms of the Creative Commons Attribution 4.0 International License (http:// creativecommons.org/licenses/by/4.0/), which permits unrestricted use, distribution, and reproduction in any medium, provided you give appropriate credit to the original author(s) and the source, provide a link to the Creative Commons license, and indicate if changes were made.

\section{Reference}

1. Sorokin L (2010) The impact of the extracellular matrix on inflammation. Nat Rev Immunol 10(10):712-723. doi:10.1038/nri2852

2. Leask A, Abraham DJ (2004) TGF-beta signaling and the fibrotic response. FASEB J 18(7):816-827. doi:10.1096/fj.03-1273rev

3. Istaces N, Gulbis B (2015) Study of FibroTest and hyaluronic acid biological variation in healthy volunteers and comparison of serum hyaluronic acid biological variation between chronic liver diseases of different etiology and fibrotic stage using confidence intervals. Clin Biochem 48(10-11):652-657. doi:10.1016/j.clinbiochem. 2015.03.020

4. Silva MB, Silva MG, Shinjo SK (2014) Serum hyaluronic acid in polymyositis: high serum levels tend to correlate with disease activity. Acta Reumatologica Portuguesa 39(3):248-253

5. Ramadori G, Zohrens G, Manns M, Rieder H, Dienes HP, Hess G, Meyer KH, Buschenfelde Z (1991) Serum hyaluronate and type III procollagen aminoterminal propeptide concentration in chronic liver disease. Relationship to cirrhosis and disease activity. Eur J Clin Invest 21(3):323-330

6. Guechot J, Poupon RE, Giral P, Balkau B, Giboudeau J, Poupon R (1994) Relationship between procollagen III aminoterminal propeptide and hyaluronan serum levels and histological fibrosis in primary biliary cirrhosis and chronic viral hepatitis C. J Hepatol 20(3):388-393

7. Guechot J, Loria A, Serfaty L, Giral P, Giboudeau J, Poupon R (1995) Serum hyaluronan as a marker of liver fibrosis in chronic viral hepatitis C: effect of alpha-interferon therapy. J Hepatol 22(1): $22-26$

8. Montazeri G, Estakhri A, Mohamadnejad M, Nouri N, Montazeri F, Mohammadkani A, Derakhshan MH, Zamani F, Samiee S, Malekzadeh R (2005) Serum hyaluronate as a non-invasive marker of hepatic fibrosis and inflammation in HBeAg-negative chronic hepatitis B. BMC Gastroenterol 5:32. doi:10.1186/1471-230X-532

9. Chu CM, Liaw YF (2010) Hepatitis B surface antigen seroclearance during chronic HBV infection. Antivir Ther 15(2):133-143. doi:10. 3851/IMP1497
10. van Hattum J, van Oudenaren A, Schalm SW, Visser JW, Benner R (1984) T-lymphocyte subpopulations in patients with various courses after hepatitis B virus infection. Scand J Gastroenterol 19(4):497-501

11. Rehermann B, Lau D, Hoofnagle JH, Chisari FV (1996) Cytotoxic T lymphocyte responsiveness after resolution of chronic hepatitis B virus infection. J Clin Invest 97(7):1655-1665. doi:10.1172/ JCI118592

12. Ahn SH, Park YN, Park JY, Chang HY, Lee JM, Shin JE, Han KH, Park C, Moon YM, Chon CY (2005) Long-term clinical and histological outcomes in patients with spontaneous hepatitis B surface antigen seroclearance. J Hepatol 42(2):188-194. doi:10.1016/j. jhep.2004.10.026

13. Arase Y, Ikeda K, Suzuki F, Suzuki Y, Saitoh S, Kobayashi M, Akuta N, Someya T, Hosaka T, Sezaki H, Kobayashi M, Kumada H (2006) Long-term outcome after hepatitis B surface antigen seroclearance in patients with chronic hepatitis B. Am J Med 119(1):71 e79-16. doi:10.1016/j.amjmed.2005.02.033

14. Harkisoen S, Arends JE, van den Hoek JA, Whelan J, van Erpecum KJ, Boland GJ, Hoepelman AI (2014) Historic and current hepatitis $B$ viral DNA and quantitative HBsAg level are not associated with cirrhosis in non-Asian women with chronic hepatitis B. Int J Infect Dis 29:133-138. doi:10.1016/j.ijid.2014.08.005

15. Lok AS, McMahon BJ (2009) Chronic hepatitis B: update 2009. Hepatology 50(3):661-662. doi:10.1002/hep.23190

16. European Association for Study of Liver (2014) EASL Clinical Practice Guidelines: management of hepatitis C virus infection. J Hepatol 60(2):392-420. doi:10.1016/j.jhep.2013.11.003

17. Sandrin L, Fourquet B, Hasquenoph JM, Yon S, Fournier C, Mal F, Christidis C, Ziol M, Poulet B, Kazemi F, Beaugrand M, Palau R (2003) Transient elastography: a new noninvasive method for assessment of hepatic fibrosis. Ultrasound Med Biol 29(12):17051713

18. Cardoso AC, Carvalho-Filho RJ, Stern C, Dipumpo A, Giuily N, Ripault MP, Asselah T, Boyer N, Lada O, Castelnau C, MartinotPeignoux M, Valla DC, Bedossa P, Marcellin P (2012) Direct comparison of diagnostic performance of transient elastography in patients with chronic hepatitis B and chronic hepatitis C. Liver Int 32(4):612-621. doi:10.1111/j.1478-3231.2011.02660.x

19. Marcellin P, Ziol M, Bedossa P, Douvin C, Poupon R, de Ledinghen V, Beaugrand M (2009) Non-invasive assessment of liver fibrosis by stiffness measurement in patients with chronic hepatitis B. Liver Int 29(2):242-247. doi:10.1111/j.1478-3231. 2008.01802.x

20. Bollyky PL, Falk BA, Long SA, Preisinger A, Braun KR, Wu RP, Evanko SP, Buckner JH, Wight TN, Nepom GT (2009) CD44 costimulation promotes FoxP3 + regulatory $\mathrm{T}$ cell persistence and function via production of IL-2, IL-10, and TGF-beta. J Immunol 183(4):2232-2241. doi:10.4049/jimmunol.0900191

21. McDonald B, McAvoy EF, Lam F, Gill V, de la Motte C, Savani RC, Kubes P (2008) Interaction of CD44 and hyaluronan is the dominant mechanism for neutrophil sequestration in inflamed liver sinusoids. J Exp Med 205(4):915-927. doi:10.1084/jem.20071765

22. Wilkinson TS, Potter-Perigo S, Tsoi C, Altman LC, Wight TN (2004) Pro- and anti-inflammatory factors cooperate to control hyaluronan synthesis in lung fibroblasts. Am J Respir Cell Mol Biol 31(1):92-99. doi:10.1165/rcmb.2003-0380OC

23. Firan M, Dhillon S, Estess P, Siegelman MH (2006) Suppressor activity and potency among regulatory $\mathrm{T}$ cells is discriminated by functionally active CD44. Blood 107(2):619-627. doi:10.1182/ blood-2005-06-2277

24. Pontinha N, Pessegueiro H, Barros H (1999) Serum hyaluronan as a marker of liver fibrosis in asymptomatic chronic viral hepatitis B. Scand J Clin Lab Invest 59(5):343-347

25. Zhang YX, Wu WJ, Zhang YZ, Feng YL, Zhou XX, Pan Q (2008) Noninvasive assessment of liver fibrosis with combined serum 
aminotransferase/platelet ratio index and hyaluronic acid in patients with chronic hepatitis B. World J Gastroenterol 14(46):7117-7121

26. Geramizadeh B, Janfeshan K, Saberfiroozi M (2008) Serum hyaluronic acid as a noninvasive marker of hepatic fibrosis in chronic hepatitis B. Saudi J Gastroenterol 14(4):174-177. doi:10. 4103/1319-3767.43274

27. Parsian H, Rahimipour A, Nouri M, Somi MH, Qujeq D (2010) Assessment of liver fibrosis development in chronic hepatitis B patients by serum hyaluronic acid and laminin levels. Acta Clin Croat 49(3):257-265

28. Li F, Zhu CL, Zhang H, Huang H, Wei Q, Zhu X, Cheng XY (2012) Role of hyaluronic acid and laminin as serum markers for predicting significant fibrosis in patients with chronic hepatitis B. Braz J Infect Dis 16(1):9-14

29. Trembling PM, Lampertico P, Parkes J, Tanwar S, Vigano M, Facchetti F, Colombo M, Rosenberg WM (2014) Performance of enhanced liver fibrosis test and comparison with transient elastography in the identification of liver fibrosis in patients with chronic hepatitis B infection. J Viral Hepat 21(6):430-438. doi:10.1111/jvh.12161

30. Kim BK, Kim HS, Park JY, Kim do Y, Ahn SH, Chon CY, Park YN, Han KH, Kim SU (2012) Prospective validation of ELF test in comparison with Fibroscan and FibroTest to predict liver fibrosis in Asian subjects with chronic hepatitis B. PLoS One 7(7):e41964. doi:10.1371/journal.pone. 0041964

31. Kim BK, Kim HS, Yoo EJ, Oh EJ, Park JY, Kim do Y, Ahn SH, Han KH, Kim SU, Park YN (2014) Risk assessment of clinical outcomes in Asian patients with chronic hepatitis B using enhanced liver fibrosis test. Hepatology 60(6):1911-1919. doi:10.1002/hep. 27389 